Kom, 2019, vol. VIII (2) : 49-65

UDC: 28-1 Ибн Араби

141.336 Ибн Араби

$28-17 / .-18$

DOI: $10.5937 /$ kom1902049S

Original scientific paper

\title{
Mystical Outcomes and Results of IbN Arabi's View on Embodiment of DeEDS
}

\author{
Mahdi Safaei \\ Faculty of Islamic Philosophy, \\ Al-Mustafa International University, Qom, I. R. Iran \\ Morteza Agha-Mohammadi \\ "Urwat al-Wusqa" Research Center, \\ Al-Mustafa International University, Qom, I. R. Iran
}

\begin{abstract}
Muslim mystics have discussed the embodiment of deeds and examined different aspects of it before philosophers. They have also paid attention to the results of this view in their discussions. One of the most important results of the embodiment of deeds is to prove the existence of a creational (Takwini) relationship between the otherworldly requitals and the deeds of mankind which, according to the proportionality of deeds and requitals, is also a basis for other worldly requitals. Another aftermath of this theory is to accept some sinful people shall remain in Hell forever, while it has been denied by the seven principles of Ibn Arabì. Based on the precedence of Allah's mercy over His rage or accidental being of human actions, the Sheikh seeks to justify the exodus of perpetrators from the everlasting retribution, while these principles have been criticized, and ultimately, their effectiveness in the cessation of the punishments has been seriously called into question. Of course, some commentators of the works of Muhyi Al-Dìn, such as Abd Al-Razzāq Kāshānī, have proved permanent punishments for human deeds based on their becoming secondary habits.
\end{abstract}

Keywords: embodiment of deeds, consistency, requitals, cessation of punishments, divine mercy

Corresponding author: safayyy@yahoo.com

Corresponding author: m_aghamohammadi@miu.ac.ir 


\section{Introduction}

One of the issues that have long occupied the minds of believers concerning resurrection as well as otherworldly punishments and rewards is the nature of the relation between human deeds and their heavenly requitals. The question is whether the relationship between them is mentally-posited and contractual or creational. In the latter case, the rewards and punishments that man receives in the afterlife are the exact embodiments of the actions he/she performed in this world, without implying any metaphorical or figurative meaning so that they are in accordance with the divine justice.

The view of embodiment of the deeds has been a question seriously raised in the works of Muslim mystics especially Ibn Arabì, and it is worthwhile to study and interpret this thought and its results in the works of great people such as Muhyī Al-Dīn. Sheikh openly declares the embodiment of deeds in Futuhät: "Every human being depends on what he has earned in the intermediate world (al-barzakh) and will be held in the form of his deeds until the Day of Judgment" (Ibn al-Arabī n. d.: I/307). This expression, in addition to declaration of the embodiment of deeds, alludes to creational relationship of human conducts with otherworldly rewards and punishments. One of his commentators also says: "Whatever human experiences after death and in the intermediary world, is exactly what he/she experiences in this world" (Āmuli 2001: III/482).

The results of the embodiment of deeds can be examined from the worldly or otherworldly aspects, as well as from individual or the social perspectives; however, given that works of mysticism are person-centered do not paid much attention to the social dimension of issues such as resurrection or embodiment of deeds, naturally there is no expectation of such discussions at least in the old mystical texts. Although contemporary mystics such as Allāmah Ṭabātabāī and late Imam Khomeini paid more attention to these dimensions as well, but given the fact that the basis of this article is the works of Muhyī Al-Dīn and his commentators, the conclusions drawn from the works of the early mystics are further elucidated.

Among the results of the embodiment of deeds, the eternal damnation of the infidels in Hell and the type of their torment have drawn more attention because almost all thinkers or mystics have entered this discussion in one way or the other. On the other hand, the particular view of Ibn Arabi and his commentators on the concept of eternal abode in Hell and the type of torture of criminals have attracted attention of other Muslim scholars. In addition to explaining the relationship between actions and requitals in the first part, worldly results of the belief in the embodiment of deeds are also examined in the last part of this paper. Despite the important position of this 
discussion among Muslim mystics, there has been no separate research on mystical results of the embodiment of deeds in mystics' view, and it has only been referred to in different books and articles. Therefore, this paper seeks to elaborate on mystical results of the embodiment of deeds. The method of research in this article is analytical-explanatory with the most emphasis on the opinions of Ibn Arabi and, to a certain extent, on his commentators after him.

\section{The Relationship between Deeds and Retributions}

The existence of a creational relation between actions and retributions based on the embodiment of actions was first expressed in the Quran (3: 28; 18: 49; 99: 7; 40: 17; 36: 54; 4:10) and it has attracted the attention of the Muslim scholars, especially mystics. Ibn Arabī (n. d.: I/307) states the creational nature of the relationship as follows: "All men in the intermediate world are indebted to their acquisitions, confined to the embodiment of their deeds till the Day of Judgment when those acts will be embodied in the otherworldly state of being." Therefore, all effects originating from human actions are, in fact, based on what man has achieved and the acts only serve as a medium. In other words, the retributions have a creational relation with the reality of deeds, and Allah Almighty keeps this reality in the higher realms and He will return them to man in the hereafter.

Referring to the verse "You were certainly oblivious of this. We have removed your veil from you, and so your sight is acute today" (Quran 50: 28), Allāmah Ṭabātabāì considers the requitals for the actions to be present in this world, but due to the negligence and the existence of the veils, man remains unable to understand them. It is because the existence of impediments and negligence becomes meaningful when the thing (the reality of actions) is already present but covered. Finally, as an interpretative rule, he introduces verses referring to the creational relationship between requitals and deeds to be the interpreters of verses which imply the existence of a conventional relationship between requitals and deeds (see: Tabātabāî 1996: VI/376-377).

According to the creational relationship between requitals and deeds, there will be no wrongdoing to man, as Allah says: "That is because of what your hands have sent ahead, and because Allah is not tyrannical to servants" (Quran 3: 182). In addition to these verses, the verses that signify Tawaffi (complete granting) of deeds in the hereafter (Quran 3:25; 39: 70), considering that Tawaffi has been accounted for the deeds themselves, not their requitals, remove any doubt about unjust being of those requitals (Țabāțabāì 1996: XVII: 296). Therefore, due to this creational relationship and the lack of 
oppression in requitals, man must only blame himself (Shảrānī 2007: 61). According to Ghazâli (1995: 342), the question of why sins lead to punishments is like asking why poison causes animals to die or why the human body has been made in a way to be affected by poison. In his view, the question of the cause of punishment is the question of the essence of the object, and according to the law of cause and effect, the impact of human actions and beliefs in his/her otherworldly requitals has to be accepted. Thus, God's punishments do not originate from His wrath and revenge, but they are natural impacts and results of human actions. Therefore, according to the doctrine of the embodiment of deeds, the relationship between deeds and requitals is beyond mental consideration or contract, but their relationship is defined on the basis of unity and identicalness that is emanated from their creational nature and that any question concerning it is a question concerning the essence of the object.

\section{1. Consistency between Otherworldly Requitals with Human Deeds}

Proving the embodiment of deeds requires confirmation of Consistency between eternal requitals and actions of man in this world, because, according to this view, requitals are nothing but actions and man in the hereafter faces the essence of his actions. In other words, since the relation of actions and requitals is a creation alone, not mere consideration. there is no alternative to accepting this Consistency at the highest level. That is why in the Quran (4: 10; 2: 174; 14: 50, 49; 20: 124; 10:27), and traditions/Hadiths (Kulaynī 1986: II/332; Saduq 1997: 3; Shuayrī n. d.: 176; Qomī 1983: I/132; Ḥurr Amilī 1988: XXVII/325) for each particular act, a particular esoteric image is expressed, and the above-mentioned consistency comes true in both quantitative and qualitative dimensions. Referring to this relationship, Sheikh Ibn Arabi (n. d.: I/219) states: "The deeds of man accompany him/her in the grave with a beautiful or ugly face and when man questions them, the answer is that we are your actions. Those who refuse to pay Zakat will be approached by a terrifying poisonous snake." He emphasizes that such Hadiths are abundant and believers accept them without any interpretations. Elsewhere he says: "The $\operatorname{dogs}^{1}$, the wicked creatures and the insidious insects of Hell are the deeds of people who hold them on the bridge of heaven" (ibid.: 316). Therefore, every act and belief has a special effect on the human soul. This effect will cause pleasure or discomfort to man after death, and given that man in this world is building his own "acquired body" in the hereafter, he will be raised with a body proportionate to his/her actions.

1 Dogs are one of the symbols of evil things in Muslims' culture. 


\section{2. A Decisive Argument against the Sinners}

One of the outcomes of the theory of the embodiment of deeds and the objective relation of deeds and requitals is to allow no excuse and room for protest on the part of sinners. The Holy Quran reads: "O faithless ones! Do not make any excuses today. You are only being requited for what you used to do" (66: 7). The verse expresses the reason for not accepting the excuses of infidels as correspondence of deeds and requitals. Abd Al-Razzāq Kāshānī (2001: II/353) considers permanent evil states in their beings as the reason for not accepting their excuses and it requires impossibility of perfection for them in the other world. Thus, correspondence between deeds and requitals rejects any oppression, so that there would be no chance for sinners to complain against the type of punishments.

\section{Other Worldly Torments and Eternality in Hell}

On the basis that every belief, action, and state has an esoteric reality, and man will be requited according to his/her own deeds, the eternality of man in heaven or Hell becomes meaningful; in other words, because of the formation of permanent states eternality gets rational. Of course, some deeds do not turn into permanent states and are removable so that they eventually disappear. Allāmah Ṭabātabāī writes in this regard: "Permanent torments are the effects of indispensable abomination of the agent. Such a person in the afterlife is like a man overtaken by melancholia who suffers due to horrible illusions and delusions. It is due to the mental state of the person without anyone having forced him/her to do so" (Tabatabai 1996: I/413).

Some commentators of Ibn Arabì have also paid attention to this point, and have considered eternal punishments as the results of the formation of evil state in man's soul (Kāshānī 2001: I/44). Now it must be seen whether mystics, like the philosophers of the Sadraiian School, accept the transformation of deeds into innate and essential character of man or they present another argument.

\section{1. The Mystical View of the Eternal Abode}

The term Khulüd (eternality) means to stay somewhere for a long time (Raghib Isfahani 1991: 292). In another definition, it is to stay without outgo (Ibn Manzuūr 1993: III/164). The second meaning i.e. not to exist, does not contradict rational arguments or Hadiths concerning the people of Paradise, but in the case of the people of Hell, various interpretations have been made, according to the two different meanings of Khulüd. Most mystics agree with 
the first meaning, and to prove it, they have appealed to diverse interpretations of religious texts. On the other hand, theologians and commentators of the Quran, by referring to the appearance of the verses of the Quran and numerous Hadiths, have accepted the second meaning and have resorted to rational and Hadithī arguments.

From Ibn Arabîs point of view (n. d.: I/303), sinners after a while get used to fire and attain its form so that they enjoy those punishments and they will be finally endowed with mercy. Due to its opposition to the appearance of some verses in the Quran (98: 6; 59: 17; 33: 64, 65; 6: 128) which indicate eternal damnation of some sinners in Hell, this view has been a matter of debate among scholars and mystics after him.

To examine and delve into mystics' views, two fundamental questions have to be treated; first, do they consider Khulüd of punishments as a long pause, or as an eternal one? And secondly, given the supposition that Hell is their eternal abode, is their torment still painful or does it become pleasing? The answer to these two questions lies in the analysis of Ibn Arabîs primary principles and those of mystics' in the face of verses of eternal torments.

As sins of sinners differ, their way of stay or departure is also different. On this basis, believers who have committed sins would leave Hell by intercession, but for disbelievers, polytheists or hypocrites mystics sometimes believe in conversion of tortures into pleasures, or sometimes they consider a complete elimination of torments and Hell's turning into a green and nice place, or they grant that the patience of people in torment increases so that the pain gets removed (Qaysari 196: 659). Thus, according to these three possibilities in the case of disbelievers, polytheists or hypocrites, their eternal stay in Hell can be something accepted by mystics, and statements regarding departure from Hell could be correct in the case of those believers who had committed major sins.

Statements of Ibn Arabì in the discussion of the removal of retribution are also different (n. d.: I/303). Sometimes he considers it to be due to the annihilation of their senses, so that their bodies do not feel the burning of it. Another time, he presumes special blessings for the people of Hell such as removal of the pains or some pleasures like those of Paradise (ibid: I/114). $\mathrm{He}$ also suggests the elimination of the barrier between Hell and Paradise and their integration in a way that bounties of Paradise will be available in Hell and the torments terminate.

Thus, mystical texts in most cases indicate acceptance of eternal life of some of the perpetrators in Hell, but they do not observe Hell to be absolutely painful, rather, divine mercy requires the removal of torments. However, it depends on the analysis of his mystical principles to find out why Ibn Arabi holds this view. 


\section{2. Principles of Ibn Arabī on the Termination of Torments}

Muhyi al-Din has presented many debates to negate everlasting torments, among them seven principles could be focused upon.

\section{First: Precedence of Divine Mercy over Divine Wrath}

The most important principle that led Ibn Arabī (ibid.: I/263) and other mystics to the rejection of eternal retribution is the precedence of divine mercy upon His wrath, which is derived from Hadiths such as "My mercy preceded My wrath" (Kulaynī 1986: I/443). Of course, mercy has a different meaning according to Muhyī al-Din (Ibn Arabi 1946: I/177). Sometimes, he is referring to mercy as a universal meaning that includes everything, and he calls this mercy Rahmānì or Imtinānì (gratuitous mercy or general mercy) (Qaysarī 1996: 913-914), a mercy equal to existence and inclusive to all beings. This meaning includes pleasing and unpleasing things. However, sometimes it is used in a specific meaning as Rahimiyah (special mercy). It is a special mercy standing for the capacity of essences or the deeds of people (Jahāngīin 1996: 348). Bearing in mind the difference between the two usages of mercy, precedence of divine mercy over divine wrath means the precedence of divine mercy in the whole universe, not with respect to specific people. In other words, the one which is subject to divine wrath is also an example of Rahmāni mercy, but it is not an example of Rahimin mercy of righteousness, and mercy has not invoked his action until wrath and, consequently, torment is present. On this basis, Ibn Arabïs intention to use these Hadiths is to suggest that special mercy will include those people in the end, because special mercy does not consist of permanent torment.

\section{Second: Obedience and Sinning}

Ibn Arabī (1946: I/94) divides divine commands into creational and defining (taklifī). Man obeys or disobeys defining rules and commands according to their A'yān al-Thäbitah (eternal hexeities); thus, their obedience requires praise and their disobedience is a sin which deserves reproach. In the eyes of the Sheikh, both obedience and disobedience are the same as the creational ones. Accordingly, everyone is destined to go to Paradise; whether for those who entered Paradise or Hell, and they merely differ in the type of boons and bounties they receive. Therefore, the difference between people of Paradise and those of Hell is in the amount of their proximity to Allah the Almighty. Therefore, the real blessing is the return of man to his/her original essence after death, and everyone will benefit from divine gifts in 
accordance with his/her state and position (ibid.: I/41-42). Based on this interpretation of obedience and disobedience, as soon as man enters the higher realms, he will receive the mercy of God. The conversion of the torment of Hell into pleasures will not have any meaning, unless we say that the suffering in Hell is also a kind of mercy and after this suffering gets habitual, then divine mercy takes on another face.

\section{Third: the Source of Torments}

Sheikh Ibn Arabi (1989: IV/533) acknowledges the deeds of man as the source of punishments and rewards, not the state which is formed after the deeds, so that he supposes good and evil deeds are kept with Allah and even though deeds are of accidental nature they will be embodied as self-subsistent beings and man will observe them. The phrase implies the embodiment of the acts themselves, not the states fixed in the human soul. Therefore, given that the aforementioned accidents (A'rädh) are not man's essence, it does not entail eternity of man in Hell, for two reasons; first, man's acts are accidental and perishable, and after they perish, their ruling will cease as well. Then, after the accidental ruling disappear, the primary principle which necessitates salvation of man will be implied (Ibn Arabi n. d.: II/213). Secondly, these deeds are finite and torments for finite actions will be finite and limited. Hence, people of Hell will eventually be saved and divine mercy will include them.

\section{Fourth: Threats and Promises}

In the Holy Quran, many verses, which are approximately equal in number, indicate promises and threats. Rationally, does Allah practice threats? Muslim mystics, including Muhyī Al-Dīn at the top, regard it possible to keep promises only, rather than threats. Sometimes, they mention customary preference (Al-Istihssān Al-'Urfī) as the proof for this (Ibn Arabī 1946: I/93-94), for the preferer to practice a threat is a sin, while Allah forgives all sins. On the other hand, Allah desires all perfections, therefore he demands admiration and praise, while there exists no praise in practice of threats, so He acts merely on his promises and not on his threats (Ibn Arabī n. d.: I/511; Jandī 2002: 406; Kāshānī 1991: 121).

Fifth: The Ultimate Perfection of Man

According to Muhyī Al-Dīn Ibn Arabi (1946: I/166), all human beings with all their differences will eventually end in salvation, therefore, ultimately, the wrath of God ceases and His mercy will include everyone. One of his 
commentators calls this statement of sheikh the argument of "transcendent and great" (Āli wa Azím) and brings two definitions of it: first, due to the inclusive divine mercy, happiness and salvation are universal in this world and the hereafter. Accordingly, affliction and misery are transitory and will be replaced by mercy, because if mercy is not universal the precedence of divine mercy over divine wrath will lose meaning. Secondly, wrath-stricken essence, given that it is an object, is included in divine mercy since Divine Mercy encompasses everything. Therefore, existence of an object is equal to its being subject to divine mercy, which means a final overtaking of mercy over divine anger (Jandī 2002: 588-587).

Hence, achieving perfection is not exclusive to the fellow of Paradise, and people of Hell will finally reach their desirable perfection, because every creature is created with wisdom and for perfection. Thus, no one will be eternally tormented, because suffering is inherently disliked. Therefore, although residents of Hell are in the fire, there are bounties for them that others do not understand (Ibn Arabī n. d.: II/673). In fact, Sheikh Ibn Arabi and his commentators created a relationship between the mercy of Rahmāniyah and Rahimiyah, and have concluded that, as existential mercy includes everything even divine wrath, mercy concerning deeds also includes divine wrath and people of Hell ultimately get Divine mercy (Jāmī 2004: 393). However, the question remains whether or not inclusiveness of the mercy of Rahmanniyah entails inclusion of the mercy concerning deeds for divine wrath and proceed it?

\section{Sixth: Determinism}

Ibn Arabī had many statements about determination and free will. Since he did not openly express his view, his commentators have expressed different opinions on his point of view; some have introduced him as an absolute determinist and made his thinking about determinism narrower than Ash'arites (Jahāngīīi 1996: 416, 422; Ibn Arabi 1946: II/158). The proof for this group lies in some of the expressions of Sheikh, because in his view, and based on the theory of the Unity of Existence (wahdat al-wujüd), all acts are done by Allah and there is no act to be done by free will, so man's free will is also caused by determination (Ibn Arabī n. d.: II/70). Besides, Sheikh (Ibid.: I/687) acknowledges that no human being enjoys free will, since their choosing capability is determined and the primary principle is coercion.

All creatures are predetermined and the primary principle is determination, so where is free will? Any creation in its existing form is in the state of determination and coercion (Ibid.). 
He also commented on the people of intuitions: "They see in their intuitions that one carries them, and they find that the Almighty is moving them ahead" (Ibid.: III/410). Also, his tendency toward Ash'arites could not be denied, because he repeatedly praised Ash'ari's theory of acquisition ${ }^{1}$, and tried to correct it. He also differentiates between the views of mystics and Ash'arites, and divides famous sayings about determination into three categories (Ibid.: III/211). Contrary to Ash'arites and in line with Mu'tazilites, he believes in ascription of acts to human beings and considers praise and reproach for the actions to be a consequence of that (see: Ibid.: I/276; II/604; III/211). In fact, Muhyi al-Dīn accepts Ash'ari view with a remark, and regards a role and influence for the will of man in performing acts.

Hence, Sheikh cannot be considered to be absolutely deterministic, or even an Ash'ari, because he identified determinism contrary to the correctness of deeds and negating the duty of man (Ibid.: I/42). In addition, in many cases, he stated that free will is essential (Ibid.: I/687). Therefore, he has an intermediate position between determinism and free will. In this regard, Sheikh in Shujūn al-Masjūn considers the viewpoint of those who see the free will of man to be subject to divine determinism to be impossible from both Shari and rational perspectives. (Ibn Arabī 2005: 75).

In spite of the moderate stand concerning determinism, Sheikh is a perfect determinist on the issue of eternal torments. He regards actions of the fellow of Hell to be in the straight path, because their will was under the authority of Allah and they had not gone to Hell with their own choice, but they were determined to go, so their distance from Allah is replaced with closeness (Ibn Arabī 1946: I/108). Some commentators of Ibn Arabī, in justifying his view, assume that divine will looks like determinism rather than determinism itself. According to them, if a group of people end in Hell, it is the entailment of their essence (Jandī 2002: 446; Qayșarī 1996: 721; Hamedāni n. d.: 589). Others see the journey of man toward Allah as deterministic (Kāshāni 1991: 154).

This determinism, whether directly ascribed to Allah or indirectly after the essences, will not make a difference in this view. According to a commentator of Sheikh, when all excuses lead to determinism, it will return to divine mercy, since Allah will not punish His creation for their deterministic deeds (Ghurāb 1995: 288).

This justification cannot prove the mercy of Allah to guilty people in the end, because if they are determined, then why should they first go to Hell

1 According to Abu al-Hasan Ash'ari, since the only creator is Allah, the human acts belong exclusively to the ancient power of Allah, and human has no effect on them. In this view, Allah when there is no obstacle, Allah creates a will in man and creates the action simultaneous to that will. The act of man is created, by Allah and at the same time it is acquired by a servant. This is called the theory of Kasb (acquisition). 
and take some pain, and after suffering, they are entitled to forgiveness and mercy? Excusing man due to the deterministic nature of his/her deeds necessitates his/her being blessed from the very beginning.

\section{Seventh: General Worship and Servitude}

Muhyī Al-Dīn (Ibn Arabi n. d.: II/213) suggests two types of requitals and rewards for both people of Paradise and Hell, one for actions and the other for servitude. Since the amount of good and evil actions in Paradise and Hell is finite, there will be rewords for the fellow of Paradise and Hell before their servitude. This reward is given to them in the light of the all-inclusive mercy of God and it is ceaseless. Accordingly, although perpetrators in the world had false claims or deeds, they knew about their falsehood; therefore, worldly false claims would be destroyed by the destruction of their vessel (the world), and only their reality as being servitude would remain; a reality that was with them in the world and the hereafter, but manifested in the hereafter. Describing the hadith of the Prophet "a good servant of Allah is Suhayb", if he did not fear Allah he would not sin", Sheikh refers to two essential worships; the second one is to follow Divine commandments and prohibitions, while, the first worship is universal and includes all humans, good or bad (Ibid.: III/402). Since essential worship is inherent and stronger, contrary to misery that is accidental, all human beings will ultimately be subject to mercy.

According to Sheikh's view, man has intrinsic and essential servitude and worship, even if he/she may happen to express the opposite, and his/ her actions and beliefs, whether they are good or bad, are accidental for the essence and will finally perish. It is only the reward for the essential reality that is permanent and endless.

\section{3. Analysis of the Principles of Removal of Otherworldly Torments}

Sheikh tries to prove special mercy of Allah, but what he proves by the Hadiths is general mercy, while punishing sinners does not contradict general mercy, since their essence is prone to be punished and special mercy does not include them. In addition, if the argument of general mercy could suffice to deny eternal torment, then it must be executed in the case of discontinuous torments and even worldly punishments, while it is obviously incorrect (Ṭabāțabāi 1996: I/414). Therefore, divine mercy goes along with perpetual torment, because it is the result of the deeds of perpetrators.

1 Suhayb ibn Sanan or Suhayb Al-Rumi is one of the companions of the prophet who converted to Islam in Mecca and immigrated to Medina. 
From the previous critique, the status of division of worship and servitude in the seventh principle is also clear, because what causes punishments and rewards is worship concerning divine commands, not general servitude. In addition, the remaining of general servitude in infidels and idolaters is problematic because it is possible that disbelief and polytheism are intrinsic and essential to them, and Allah says, referring to their case: "Indeed Allah does not forgive that any partner should be ascribed to Him, but He forgives anything besides that to whomever He wishes" (Quran 4: 48, 116). It is clear that not forgiving is in the Hereafter, otherwise in this world they will receive divine mercy and blessings if they repent.

Mystics also express ultimate perfection of man in the light of God's encompassing mercy and express it as the cause of man's perfection. Therefore, according to the critique that was brought about by divine mercy, the fifth principle will not work either.

His second principle is also ill, because if disobedience is the same as obedience, then why people of Hell initially suffer from torments and eventually this torment turns to be sweet? In other words, why from the beginning, like the fellow of Paradise, don't they enjoy blessings of the afterlife?

The third principle of Sheikh is also insufficient to prove that torments are everlasting. In other words, to consider deeds and their consequences accidental entails the torments of the hereafter to be perishable, so it could be criticized basically.

About the fourth principle, confusion has happened between the possibility and the necessity of Allah's abandoning His threats. Thus, it is possible for Allah to decide against punishing the guilty and not practice His treats, and even Imamiyah School believes in the goodness of this (Mufid 1992: 68), but it does not necessitate this forgiveness upon Allah. Therefore, Allah has conditioned His forgiveness for the criminals to His will: "Then He will forgive whomever He wishes and punish whomever He wishes." The same concept has been presented in many verses (see: Quran 2: 284; 3: 129; 5: 18, 40; 9: 15, 27; 29:21; 48:14). In addition to the Quranic verses, there are some Hadiths in this regard (Barqi 2004: I/246).

Ibn Arabï's view on the denial of permanent torment can be summarized in two elements: one is the torments being accidental and the other is the inclusion of divine mercy. Of course, the idea of man's being determined to reach his otherworldly state has also had a profound effect on this thinking. Given the definition of mercy and the fallacy made in this argument, as well as the invalidity of the belief in determinism, it only remains to appeal to the accidental character of torments that is dependent on perishability and accidental being of deeds; therefore, if the theory of impossibility of deeds turning essential is rejected, there will be no choice 
except to consider torments as perishable, unless by appealing to Transcendent philosophy (al-Hikmat al-Muta'alizah), we reject this theory and accept that deeds and beliefs of man can transform into his/her essence (Sadr al-Din Shirazi 1981: IX/290).

Ibn Arabì (n. d.: II/183; IV/22) noticed that human actions are accidents and accidents do not remain in two different periods, therefore, he ascribes their durability and permanence in the hereafter to divine power. According to the mystical viewpoint, at least two justifications can be considered for this; one is the breadth and extent of the World of Forms (Ālam al-Mithāl) and the possibility of the co-presence of two contradictions or two converses in this world (Ibid.: I/306), which makes the alteration of accidents into substancespossible. The other justification is based on the adaptation of the Worlds and the presence of the esoteric aspect of deeds in that world. In this case, there is no contradiction between the accidental being of actions in this world and the remaining of their esoteric existence in other worlds, and what is embodied is the reality of actions. The first justification is not rationally acceptable, and it is in mystical terminology "beyond the stage of reason", but based on the second justification, one can imagine the embodiment of actions in the assumption of their being accidents, so the permanent torment will be indispensable and perishable.

\section{Worldly Results of the Embodiment of Deeds}

In Ibn Arabïs view (n. d.: II/186), this world is a place of negligence and the hereafter is the world of awakening. Negligence that afflicts man in this world is due to the veils that have been cast upon their hearts (Jāmī 2004: 302). Now, how can the veils be removed? The answer to this question can be found in Hadiths, such as a narration quoted from Imam Sādiq: "Remembering death annihilates lustful desires in the soul and removes the roots of negligence and increases hope in the glad tidings of Allah" (Ja'far ibn $\mathrm{Mu}$ hammad 1979: 171). Therefore, remembrance of death and examination of the soul takes away negligence from man and causes him/her more awakening in the worldly life, especially when according to the principle of the embodiment of deeds, we define requitals same as the acts of man. In other words, the idea that requitals are the deeds themselves, in the world, will surely have a deeper influence on awakening man.

On the other hand, perpetuity of acts and their presence in the esoteric aspect of the world also increases mindfulness of man, because if a person is certain that his/her actions will not be lost, rather they will be embodied and will accompany him/her in this world, the intermediate world as well as in the hereafter, then he/she will be more careful about his/her actions and 
beliefs, for human dignity in the hereafter is based on his/her actions and beliefs, and this makes man struggle for self-purification before death. Such a man gets inspired and awakened by the events in this world and avoids carnal desires and satanic temptations (Haqqī Brūsawī 1984: V/50).

Intuitions and observation of the esoteric side of deeds, in a level higher than having knowledge about them, eliminates worldly veils and negligence; thus, mystics in this world will comprehend the truth and the essence of actions which others will understand in the hereafter, as Sayyid Haydar Āmuli declares (2001:580) - intuition of the celestial kingdom of the world is equal to the removal of obstacles and veils, the veils that Allah introduces in the verse "You were certainly oblivious of this. We have removed your veil from you, and so your sight is acute today" (Quran 50: 22). Therefore, observing the celestial kingdom, which embodied acts of man in the intermediate world are part of (Qayșarī 1996: 135), will remove the veils and eliminate negligence of a wayfarer.

One of the issues related to awakening that can be brought about by the belief in the embodiment of deeds is feeling responsibility. Allāmah Ṭabātabāī says: "The Lord cannot be reached without servitude and servitude depends on responsibility and it relies on examination of deeds and it cannot be done without requitals of deeds" (1996: XX/243). Accordingly, the completion of the lordship, servitude, responsibility, and examination of actions depend on requitals of deeds, and the highest degree of requitals is if worldly practices are the same as otherworldly requitals and anyone who practically or intuitively believes in the embodiment of acts would have the highest responsibility for his/her actions. Besides, laws and regulations need enforceable warrant to be practiced, and it is because of rewards and punishments for actions. Therefore, identification and union of actions and requitals will function as an enforceable warrant for the performance of the divine law in its highest level.

\section{Conclusion}

There is a consistency between deeds and requitals in both conventional and creational requitals, however, it is more powerful and effective in the latter, since in the embodiment of acts, there is no otherness between actions and requitals, and all that human beings achieve as rewards or torments in the hereafter is nothing but esoteric reality of their worldly deeds. In the eyes of mystics, the world and the hereafter are in accord with each other, and according to the verse "on the day when the secrets are examined" $(Q u-$ ran 86: 9), the interior of this world is apparently exposed in the hereafter; hence, the interior of man's actions accompanies him/her in this world as 
well, albeit majority of people do not understand this companion, but their sight gets sharp in the hereafter: "You were certainly oblivious of this We have removed your veil from you, and so your sight is acute today" (50:22) and ultimately they will only find knowledge of this company, not requitals to be created in the hereafter.

This consistency and union negate any kind of oppression, and torments are the same as the essence of their object and their cause are sins. Thus, criminals' complaining about punishments will be meaningless, because they have destroyed their essence through the penetration of mean and evil forms in it and have deprived themselves of perfection.

But the most important worldly result of the theory of embodiment of actions, is to make man take care of his/her actions and behavior, because the presence and the accompaniment of actions with their agents and their appearance in the hereafter, will eliminate negligence and lead to his/her endeavor to purify the soul. The elimination of ignorance and negligence is realized in two stages; the first stage is with the knowledge about the embodiment of actions, and the second is the observation of the interior of the acts in this world. From the mystics' point of view, the veils referred to in the verse 22 of chapter 50 are removed with the witnesses of the celestial kingdom of deeds and a wayfarer finds an acute sight. Also, as a human takes more care of deeds and beliefs, the level of his/her responsibility increases.

The most controversial discussion concerning the embodiment of deeds are permanent torments of criminals in Hell. Those who have accepted the conversion of deeds into permanent states and essential characters and have considered retributions as integral and inseparable parts of some of perpetrators, have confirmed eternal torments. But, from the point of view of some mystics and scholars, the torments are constrained and accidental. Accordingly, sinners will finally be free from Hell, or their torments will turn into pleasures. The first view belongs to Sadraian philosophers and some mystics, while the second view is confirmed by current Muslim mystics. Ibn Arabi and most of his commentators, on the basis of the seven principles mentioned, sometimes denied eternal residence in Hell and sometimes interpreted permanent torments. However, those principles are subject to internal and external criticisms.

Abd al-Razzāq Kāshānī, before Mulla Sadrā, suggested the discussion of the transformation of human actions and beliefs into fixed states in the soul and then their turning into the essence of man (Kāshānī 2001: I/44). On this basis, he believed that some criminals will be eternally suffering in Hell. In contrast to this viewpoint, Muhyi al-Dīn, considering deeds of man as accidents, believed in the perishable nature of torments. Being aware of accidental and perishable nature of the deeds, he does not provide a rational 
justification for their manifestation in the hereafter, and only ascribes it to the great power of Allah. However, considering critiques of mystics' principles and the lack of compatibility of the denial of eternal residence and torments in the hereafter with the Holy Quran and Hadiths, it is difficult to accept this view.

Received: August $8^{\text {th }}, 2019$.

Accepted: November $22^{\text {nd }}, 2019$.

\section{References}

The Holy Quran.

Āmulī, Sayed Haydar (2001), Tafsìr Al-Muhì Al-A'zam, edited by Muhsin Mūsawī, Tehran, Ministry of Irshād Islami Publication.

Barqī, Ahmad bin Muhammad (2004), Sharh Fusūs Al-Hikam, eidted by Āsim Ibrāhīm Al-Kīalī, Beirut, Dār Al-Kutub Al-'Ilmīyyah.

Ghazālī, Abu Hāmid Muhammad (1995), Majmu’a Rasāil Al-Imām al-Ghazālì, Beirut, Dār Al-Fikr.

Ghurāb, Mahmud (1995), Sharhu Fuṣuṣ al-Hikam, Damascus, NPD.

Ḥaqqī Brūsawī, Ismāīl (1984), Tafsìr Ruh Al-Bayān, Beirut, Dār al-Fikr.

Hamedānī, Sayed Ali (n. d.), Hallu Fușūṣ Al-Hikam, Irfan digital collection, Qom, Computer Research Center of Noor.

Ḥurr Amilī, Muhammad ibn Ḥassan (1988), Tafșìl Wasāil al-Shia Ilā Tahṣìl Masāil Al-Sharia, Qom, Ahl Al-Bayt Institute.

Ibn Arabī, Muhyī Al-Dīn (n. d.), Al-Futūhat Al-Makkìiyah, Beirut, Dār Al-Sādir.

Ibn Arabī, Muhyī Al-Dīn (1946), Fusus Al-Hikam, edited by Abu A’lā Afîfì, Cairo, Dār Ihya Al-Kutub Al-Arabīyyah.

Ibn Arabī, Muhyī Al-Dīn (1989), Rahmatun Min Al-Rahmān fi Tafsìr wa Ishārāt Al-Quran, edited by Mahmūd Muhammd A-Ghurab, Damascus, Nadhr Publication.

Ibn Arabī, Muhyī Al-Dīn (2005), Shujūn al-Masjūn wa Funūn Al-Maftūn, edited by Ali Ibrāhīm Kurdī, Damascus, Dār Sảd Al-Dīn.

Ibn Manzur, Muhammad bin Mukram (1993), Lisān Al-'Arab, edited by Jamāl Al-Din Mir Dāmādi, Beirut, Dār Al-fikr.

Ja’far ibn Muhammad (1979), Miṣbāh al-Sharia, Beirut, Institute of Al-A'alamī.

Jahāngīrī, Mohsen (1996), Muhyī Al-Dīn ibn Arabī, Chehreye Barjasteye Erfäne Eslāmī, Tehran, Tehran University Press. 
Jami, Abd Al-Rahman (2004), Sharh Fusūs Al-Hikam, eidted by Āsim Ibrāhīm Al-Kīalī, Beirut, Dār Al-Kutub Al-Ilmīyyah.

Jandī, Mu'ayyed al-dīn (2002), Sharh Fușūs al-Hikam, edited by Sayed Jalāl Al-Dīn Ashtīānī, Qom, Bustāne Ketāb.

Kāshānī, Abd Al-Razzāq (1991), Sharh Fuṣụ̄ al-Hakam, Qom, Bidār.

Kāshānī, Abd Al-Razzāq (2001), Tafsìr Ibn Arabī (Ta’wìlāatu Abd Al-Razzāq), edited by Samīr Mustafā Rabāb, Beirut, Dār Ihyāa al-Turāth al-Arabī.

Kulaynī, Muhammed ibn Yảqub (1986), Al-Kafì, Tehran, Dār Al-Kutub al-Islāmìyyah.

Mufìd, Muhammad ibn Muhammad (1992), Al-Fușūl al-Mukhtārah, edited by Ali Mìr Sharîfi, Qom, Sheikh Mufid Congress.

Qayșarī, Dāvud (1996), Sharh Fușuss al-Hikam, edited by Sayed Jalāl Ashtiānī, Tehran, Elmī wa Farhangī Publication.

Qomī, Ali ibn Ibrahīm (1983), Tafsìr al-Qomī, Qom, Dār Al-Kutub.

Rāghib Isfahānī, Hussain ibn Muhammad (1991), Mufradāt Alfāz Al-Quran, Beirut, Dār al-Qalam.

Șadr al-Dīn Shīrāzī, Muhammed ibn Ibrāhīm (1981), Al-Hikmah al-Mutāàlīyah fì al-Asfär Al-Aqalìyah al-Arba'a, Beirut, Dār Ihyā Al-Turāth al-Arabì.

Șaduq (Ibn Bābawayh), Muhammed bin Ali (1997), Al-Amālì, Tehran, Ketābchī.

Sha'rānī, Abd Al-Wahhāb (2007), Al-Jauhar Al-Masun wa Al-Sir Al-Marqum fìmā tantajih Al-Khalwāta Min Al-Asrār wa Al-'Ulum, Cairo, Dār Jawāmi' Al-Kalim.

Shuayrī, Muhammad ibn Muhammad (n. d.), Jāmì Al-Akhbār, Najaf, Heydarīyah publication.

Țabāțabāī, Muhammad Husain (1996), Al-Mīzan Fī Tafsìr al-Quran, Qom, Islamic publication of Jāmi’a Al-Mudarrisīn. 